\title{
TOSCA, A WORKSHOP ON ARCHITECTURAL BUILDING SOLUTIONS: CHANGING THE WAY BUILDING PRODUCT INNOVATION IS TAUGHT
}

\author{
Joan-Lluís Zamora i Mestre, PhD architecture \\ Vallès School of Architecture (ETSAV), Universitat Politècnica de Catalunya \\ joan.lluis.zamora@upc.edu
}

\begin{abstract}
Innovation is humans' way to find new solutions to new problems. To make innovation a reality, new ideas must take shape and be tried out. Most polytechnic university students' daily focus on solving technical problems by applying existing and verified solutions: a repertoire of technical construction solutions typified by good practice and approved by the regulatory framework. But today there are some boundary conditions in the building industry that bring about changes in the way we educated on construction technology:

- New requirements for sustainable technical development.

- Social, production and climate changes that are affecting the entire planet

- New forms of production management and technical knowledge.

- New professional roles.

All these changes are developing quickly and causing the obsolescence of the current production range of industrial construction model:

- Characteristics of existing building products are no longer suited to current needs.

- Professional services that are currently provided no longer reflect social dynamics.

- Current flows of extraction, manufacturing and transportation of building products, construction, maintenance and demolition is not in line with biosphere cycles.

One response to these challenges has been to introduce the ToSCA workshop, which is an academic space for building product innovation. The aim of this optional subject is to open the minds of architecture students. Annual ToSCA exercises can be consulted at: http://ocw.upc.edu/curs/47052-2012/4 and also at the next web issue.
\end{abstract}

Key words: innovation, building technologies, education, workshop 


\section{INTRODUCTION}

Construction has always been a down-to-earth productive sector. The construction sector in Western society has constructed buildings for centuries that are marked by the legacy of the classics, and the moral weight of tradition has hindered any new initiative. Industrialization has slowly changed this situation and has placed innovation in a pre-eminent position for active construction in the future. Everyone agrees that it is an industry with great respect for tradition and experience [1].

Architecture is a discipline that combines many varied skills from the fields of fine arts, science, humanities, health and economy, among others, and from building technologies. Innovation in building has generally been focused on design, which is probably one of the reasons why architecture is one of the few techniques to have entered the world of fine arts. Some entrenched concepts, such as knowledge of the classics and the rules of the art and practice, reappear time and again and permeate historical architecture and construction [2].

However, buildings serve a society that is increasing number and impact of changes dramatically. The availability of new materials, the shift of production to factories and the new functional programs in recent architecture have led to the constant search for new construction solutions. Max-Neef [3] describes the nature and development of human needs, making it clear that there is not only one way to uniquely satisfy them. In fact, the way we satisfy our needs is probably our main difference from other civilizations.

The driving force that is located behind the latest technical innovations in construction has been seeking greater well-being for citizens of a major economic benefit for shareholders of companies that drive innovation. However, the rapid attainment of material wealth in Western societies has also generated the concept of risk quantification in the form of bonuses, and the petrifaction of the normative, additions that have occurred at the end brakes to initial innovation. This is probably why a gap has opened up between building's technical standards and unique super buildings. Innovation has recently only focused on such super innovative buildings, creating a complacent architectural extravaganza that is called on media as high tech.

Recently, construction innovation receives new extra impetus, heavily influenced by the planets' need for environmental balance and peoples' need for social cohesion.

\section{Education for innovation or innovation in education?}

Innovation is one of the expressions of human intelligence that comes to the fore in the technical decision-making process, which focuses in particular on reducing uncertainty. Anything that does not have an existing solution assigned in building plans must necessarily be innovated.

As a result of this new paradigm, the university must rethink the education system that trains the professionals who will drive this innovation. At this time, one of the educational challenges that most schools of architecture face is the introduction of appropriate technical skills into the training of future architects. 
What should be the profile of professionals who promote this innovation? What is the profile of professionals who should develop this innovation? What is the profile of professionals who should apply this innovation? What is the profile of professionals who should verify this innovation? Society needs innovative professionals with competences to promote, develop, implement and verify the technical innovation.

In order for innovation to develop, there must be motivation among technical professionals, social dissatisfaction in the community, tools to develop the knowledge, suitable technical environment, and an education oriented to innovation.

What should education for innovation be like? The professionals and technicians who will guide future innovation are today educated at universities. However, most of their current training is not innovative. In many cases, transmission of knowledge is considered at universities more important than the promotion and development of innovative spirit.

Innovation in the nineteenth century was based on the effort of many great individual inventors, but we are now moving towards the development of communities of innovation, as social reality is multifaceted, sensibilities are not shared, and knowledge tends to be highly specialized.

For some years, there has been tacit agreement on the educational success of a learning method based on project workshops that address case studies. This educational method seems to be able to qualify students to resolve real cases presented in the form of issues.

However, architectural building techniques are still taught, in most cases, as a stable repertoire of rules and a catalogue of typified solutions selected by good practice and sanctioned by the regulatory framework.

In this context, and from the perspective of architecture schools located in technical universities, the aim of this communication is to express an experience of an education space to foster construction innovation, based on the following assumptions:

- An architectural workshop can also run well to develop innovative building solutions.

- Technical Innovation can be applied to products oriented to building construction.

- Innovation outputs comes from common stock, which is the innovation community.

- Innovation can be an addition added to the basic skills of higher education.

- Innovation comes from common stock, which is the innovation community.

- Innovation can be an addition added to the basic skills of higher education.

A group of professors from the Universitat Politècnica de Catalunya (UPC), who are concerned about the technical education of future architects, consider that these new boundary conditions advise about to foster competences on technical innovation on technologies in architecture. In this context, we present the experience of a specific intensive workshop that has run from 2007 at the Vallès School of Architecture (ETSAV). 
"If the answer is the engine of evolution, the question is what triggers the revolution." [4]

\section{OBJECTIVES}

The several goals for introducing this intensive workshop as an optional topic into the architecture curriculum at ETSAV were:

1. Verify whether the traditional methodology used for the architectural design courses (an education workshop to resolve a real case study) could be applied to training in construction techniques.

2. Verify whether the proposed workshop could include the figure of the client, who usually commissions the architect to solve a technical problem.

3. Verify whether architecture students could carry out the work of industrial designers in defining new building products and apply their skills to solve a problem that is not a whole building, but some of its constituent technical parts such as systems, products or materials.

4. Verify whether training in innovation can help architects to become active designers of construction products and to develop knowledge of the associated techniques, rather than passive prescribers of commercial construction products.

5. Verify whether architecture students can use other skills during their university training period that are innate to architecture, and assess whether their core professional profile allows them to adopt roles other than the traditional one of building designer and construction works director.

\section{ACADEMIC IMPLEMENTATION}

The implementation of an innovative educational experience requires some environmental conditions that favour the proposed activities. In the outline of the project, it was proposed to establish a working student environment characterized by the following:

- The workshop should be optional in order to ensure that participating students are willing and motivated.

- A maximum of 30 students should be enrolled on the workshop. Students should be as mixed as possible, so it was decided to encourage the presence of students from the Erasmus exchange system within the European Higher Education Area (EHEA). This decision was made to favour group cohesion and constant intercommunication.

- The workshop must be developed in only one classroom, where the furniture can be easily removed around to create different areas (general assemblies, minor meetings, work groups), to foster different forms of educational dynamics throughout the academic period (1 week).

- The workshop should be intensive (40 hours) and continuously from Tuesday to Monday (contents a week end), to achieve the best interaction between students and deep immersion into the proposed topic. Standard university courses are usually strictly compartmented by the daily schedule but this is not the case in real professional life. Therefore, it seemed a good idea for the academic activities to be carried out continuously as a unit of training. Immersion in just one topic requires students and teachers to contribute all of their available resources.

- A different topic must be tackled in each annual edition of the workshop, in order to provide guidance on current issues and avoid the consolidation of conventional answers. The topic is proposed by a different construction product company every edition of ToSCA, and this company must be physically present at every 
edition of ToSCA. Construction product companies usually go to universities to present their products, but never to share knowledge and concerns about them. Thus, this workshop can strengthen ties within the future professional community of the construction sector.

- A junior lecturer should be involved in the ToSCA workshop. This collaborator should adopt the role of relator, collecting and recording the living memory of the intensive course during the week of its duration. Finally, the junior lectures edit all the issues of ToSCA in a digital support (CD or web page) distributed for every participant and offer to the construction product company.

- Training for innovation must be developed in a cooperative framework. That is why, working groups formed by three students were implemented. Each of these three students holds the responsibility of a role: role of design, role of development and role of diffusion. Each of these three roles refers to one of the three parameters that evaluate the jury External novelty, rigor and communication.

- The end result achieved in the workshop by every working group should be assessed by an external panel. This decision provides two advantages: firstly keeps the pace of work between students and teachers until the last day. On the other hand puts the central focus of the work of teachers in the educational process and not on the outcomes of this process.

The Board of the Vallès School of Architecture (ETSAV) agreed to implement all these points, raised by the educational team of professors from the Department of Architectural Technology. The first edition of the teaching experience took place in January 2007. From then, 7 editions of this workshop have been run, and around 300 students have completed this training in technical construction innovation. This intensive course is held every edition in the $3^{\text {rd }}$ week of January, as this is a transition academic period between the two semesters in which there are no other academic activities. As a result, the period of intensive work on ToSCA does not affect other regular subjects in the architecture curriculum.

\section{ACADEMIC DEVELOPMENT}

ToSCA is a workshop with an underlying message: there is no single technical solution for every problem of building materials and architecture. There is chance for innovation. So the whole innovation community, consisting of professors, the company and the students, should be able to generate and assess the largest number of possible solutions to the proposed challenge and then evaluate, prioritize and implement them.

ToSCA runs as a short and accelerated process (one week) in which uncertainty is reduced to obtain a detailed profile of every alternative, fostering the collaboration of the entire group.

\section{The selection of topics}

Every edition, when the annual workshop ends, the following year's innovation topic is discussed. It is important not to repeat the same topics, to search for a new construction product company to sponsor next ToSCA edition and share all its concerns with the academic team.

\section{The week schedule}

ToSCA now has a standard work schedule, so that every stage of decisionmaking takes place in parallel with the days of the week. An example of the standard schedule is shown below: 


\begin{tabular}{|c|c|c|c|c|c|}
\hline $\begin{array}{l}\text { TOSCA } \\
\text { SCHEDULE }\end{array}$ & $\begin{array}{l}\text { DAY } 1 \\
\text { Tuesday }\end{array}$ & $\begin{array}{l}\text { DAY } 2 \\
\text { Wednesday }\end{array}$ & $\begin{array}{l}\text { DAY } 3 \\
\text { Thursday }\end{array}$ & $\begin{array}{l}\text { DAY } 4 \\
\text { Friday }\end{array}$ & $\begin{array}{l}\text { DAY } 5 \\
\text { Monday }\end{array}$ \\
\hline $09.30-10.30$ & $\begin{array}{l}\text { Introduction of the } \\
\text { subject to the } \\
\text { group: } \\
\text { - Objectives } \\
\text { - Work process } \\
\text { - Presentation } \\
\text { rules: granting } \\
\text { rights } \\
\text { - UPC Repository } \\
\text { - Teaching team } \\
\text { - Provisional } \\
\text { training groups } \\
\text { Moodle platform }\end{array}$ & $\begin{array}{l}\text { OUTDOOR } \\
\text { ACTIVITY: } \\
\text { "IMAGE } \\
\text { HUNTERS" } \\
\text { Express in } \\
\text { photos the } \\
\text { building } \\
\text { environment } \\
\text { around the } \\
\text { university, to } \\
\text { capture notable } \\
\text { realities related } \\
\text { to the workshop }\end{array}$ & $\begin{array}{l}\text { Brainstorming in } \\
\text { groups }\end{array}$ & $\begin{array}{l}\text { VALIDATION } \\
\text { FEASIBILITY } \\
\text { INSERTION } \\
\text { SUSTAINABILITY } \\
\text { Working in parallel, } \\
\text { evaluating different } \\
\text { alternatives }\end{array}$ & $\begin{array}{l}\text { PUBLIC } \\
\text { PRESENTATION } \\
\text { OF THE FINAL } \\
\text { PROJECTS } \\
\text { Assessment of } \\
\text { the Tosca } \\
\text { community } \\
\text { EXTERNAL } \\
\text { JURY }\end{array}$ \\
\hline $10.30-11.30$ & $\begin{array}{l}\text { LECTURE } 1 \\
\text { (Sponsor) } \\
\text { Visit to the } \\
\text { sponsor's factory }\end{array}$ & & & & \\
\hline $11.30-12.00$ & \multicolumn{5}{|l|}{ COFFEE BREAK } \\
\hline $12.00-13.00$ & $\begin{array}{l}\text { PUBLIC DEBATE } \\
\text { - Objectives, } \\
\text { requirements and } \\
\text { regulations } \\
\text { - Subjective } \\
\text { requirements for } \\
\text { different agents } \\
\\
\text { Debates in which } \\
\text { students } \\
\text { represent different } \\
\text { positions: } \\
\text { developer, } \\
\text { applicator, user, } \\
\text { architect, etc. }\end{array}$ & $\begin{array}{l}\text { PUBLIC } \\
\text { PRESENTATION } \\
\text { OF RESULTS } \\
\text { OF THE } \\
\text { PREVIOUS } \\
\text { JOINT } \\
\text { ACTIVITY: } \\
\text { "HUNTERS" } \\
10 \text { photos posted } \\
\text { by group }\end{array}$ & $\begin{array}{l}\text { PUBLIC } \\
\text { PRESENTATION } \\
\text { Student groups } \\
\text { declare } \\
\text { leitmotifs, } \\
\text { objectives and } \\
\text { briefing. }\end{array}$ & $\begin{array}{l}\text { PRESENTATION } \\
\text { AND } \\
\text { COMMUNICATION } \\
\text { STRATEGIES }\end{array}$ & $\begin{array}{l}\text { FINAL DRINKS } \\
\text { FAREWELL }\end{array}$ \\
\hline $13.00-14.00$ & $\begin{array}{l}\text { BENCHMARKING } \\
\text { PRODUCTS }\end{array}$ & $\begin{array}{l}\text { APPLICATION } \\
\text { OF S.W.O.T.: } \\
\text { Strengths } \\
\text { Weaknesses } \\
\text { Opportunities } \\
\text { Threats }\end{array}$ & $\begin{array}{l}\text { Creation of } \\
\text { poster sheet } 5\end{array}$ & & \\
\hline $14.00-15.30$ & \multicolumn{5}{|l|}{ LUNCH } \\
\hline $15.30-17.30$ & $\begin{array}{l}\text { Creation of poster } \\
\text { sheet } 1\end{array}$ & $\begin{array}{l}\text { Creation of } \\
\text { poster sheet } 3\end{array}$ & $\begin{array}{l}\text { LECTURE } 2 \\
\text { Independent } \\
\text { expert on the } \\
\text { topic }\end{array}$ & & \\
\hline $17.30-18.00$ & \multicolumn{5}{|l|}{ COFFE BREAK } \\
\hline $18.00-20.00$ & $\begin{array}{l}\text { Creation of poster } \\
\text { sheet } 2\end{array}$ & $\begin{array}{l}\text { Creation of } \\
\text { poster sheet } 4\end{array}$ & $\begin{array}{l}\text { Creation of } \\
\text { poster sheet } 6\end{array}$ & $\begin{array}{l}\text { Preparation of the } \\
\text { proposal }\end{array}$ & \\
\hline
\end{tabular}




\section{Day 1, Tuesday}

This is the first day of the intensive workshop, and it is when the new topic is presented and the academic dynamics of the technical innovation workshop are explained. The team of professors is introduced and students form the first provisional working groups. In addition, the Moodle e-learning platform is presented, as this is the backbone of ToSCA and facilitates the group's joint work and communication.

The group of students and professors visit the sponsor factory to learn about the focus product, the manufacturing process, and the current approach to the problem.

After a coffee break, there is an open public debate in which students propose the requirements and conditions of consensus that must be applied to the specific problem. Students should adopt different real positions in their speeches: architect, user, builder, manager, etc. to understand the different interests and perspectives that are always taken into account when a technical problem is solved in an innovative way.

The first morning of joint work ends with a benchmarking session, during which the student groups are encouraged to collect all the information that could be used as a reference to solve the problem. [6][7][8][9]

After lunch, student groups are formed to put the information generated and collected in the morning onto poster sheets nos. 1 and 2. This dual format (morning time for action, afternoon time for compilation) was chosen because it is much closer to the synthetic thinking of architecture.

\section{Day 2, Wednesday}

As students are already steeped in the subject, they are asked to go out around the university building, in the town of Sant Cugat $(75,000$ inhabitants, $10 \mathrm{~km}$ from Barcelona), to identify real problems and opportunities on the streets and public buildings. Portable digital cameras are used to capture the reality, which is why the activity is called "image hunters". Each group of students chooses the 10 most representative images to present them in the public joint debate.

After the coffee break, there is another session in the form of a public debate in which all the students present the strengths, weaknesses, opportunities and threats posed by the topic (SWOT methodology) from the perspective of different positions. In the afternoon, every group of students begins to arrange the information generated in the morning on poster sheets nos. 3 and 4.

At this point, students are making progress by observing and depositing everything that they have discovered onto the drawing sheets. However, at this point they are not asked to propose any innovative technical solutions to the problem. The aim is to keep them deliberately at this stage of observation and analysis, which is the basis of technical innovation.

\section{Day 3, Thursday}

Every student works within their group through a brainstorming session to find a variety of technical alternatives to the topic problem. For each previously selected alternative, they must seek a leitmotif, objectives and a way of developing the idea, with the consensus of all the roles involved.

After the coffee break, the teams of students present their proposals for debate at a public meeting. The objective is to select by screening the alternatives that will be discarded and the alternatives that will be developed further. If there are 
similarities between some alternatives presented by different groups, strategic alliances are promoted to avoid unnecessary duplication. On this $3^{\text {rd }}$ day, the members of some student groups may change, by regrouping or splitting up.

In the early evening, an independent expert comes to visit the workshop. This consultant gives a brief lecture on recent developments in the problem area and answers the student groups' questions on technical details. The objective of this session is to strengthen the students' technical proposals, which will be developed the next day.

\section{Day 4, Friday}

In the morning, the student groups develop technical aspects of their respective proposals. They specify technical details, potential suppliers, the commissioning of work, etc. and ensure that their proposals are viable and innovative. During this phase, the direct support of the professors is vital, to coach students on the problems, maintain an open outlook, focus efforts, prioritize issues and examine the set of alternatives to provide an overall, solid, varied repertoire of possible responses to the problem. Through this direct contact, the lecturer must transmit a passion for innovation.

After lunch, the work focuses on communicating the proposals. Innovation can only occur when new ideas are really transferred to society. Students are aware that on next Monday their proposal will be considered by an external jury. In a limited time of $15-20$ minutes, the jury must be able to grasp the work of every group, its interest, novelty and rigour. Therefore, the visual and oral presentation is essential, and this is an area in which undergraduate architecture students do not always excel.

\section{Days 5 and 6, Saturday and Sunday}

These two days are not teaching days, but students themselves can meet or communicate with each other to fine-tune their work and ensure that on Monday, the final day of the workshop, everything is ready to convince the jury. This period is outside of the professors' supervision, but in the last few editions, it was found that this private period was essential for final success.

\section{Day 7, Monday}

In the degree hall of the Vallès School of Architecture (ETSAV), the student working groups present with passion their innovation proposal to the jury through a short oral presentation accompanied by a digital projection (PowerPoint or similar). Scale models or some marketing techniques are frequently used to complement the presentation. The external jury's questions are answered.

The evaluation

The end point of any educational activity is the evaluation process. Therefore, an external panel is established for this purpose. The jury usually consists of:

- A professor from the Construction Department who is not directly involved in ToSCA

- A professional, representing the sponsor company

- An independent expert from the construction sector 
The panel assesses three separate aspects of the proposals:

- Novelty of the innovation

- Accuracy of the proposal

- Presentation and communication of the proposal

After the joint public presentation, the jury deliberates in private. Subsequently, the jury gives the entire audience in the hall its qualitative assessment of all the presented proposals. Then, all participants are invited to a farewell party to strengthen their bonds as an innovation community formed during the intense week. The quantitative evaluation ( $\mathrm{a}$ mark) is announced the next day by the usual academic channels.

\section{BALANCE AND SATISFACTION}

\section{The sponsor company}

A wide range of companies have sponsored previous editions of the ToSCA workshop, including Pladur, Technal, Lubrizol, Unex, Terreal, Adelec, etc. which represent a variety of market positions, from local to multinational, from material (micro) to product (meso) and system (macro). Satisfaction has been high as the companies have noted that the university addresses their concerns and offers in a short period of time interesting innovation proposals to improve their responses to the concerns of the sector and society. There has been a high level of anticipation about some proposals, which led to valid alternatives for future developments.

\section{The students}

Students have expressed their satisfaction with this educational initiative in different ways. Firstly, the optional workshop's excellent reputation has led to the places being filled every year to date. Secondly, in annual satisfaction surveys of the UPC, students have given ToSCA 9 out of 10. Students' satisfaction may be due to the fact that the workshop increases their knowledge and they enjoy a new educational format that allows them to use some skills that are not always recognized within the standard curriculum, such as technical innovation. Students also expressed satisfaction in private conversations, in which they recognized the usefulness of this short, intense workshop, which provides a hint of tension within the dense academic periods.

The professors

Lecturers participating in the ToSCA workshop have been changing through the different editions, but all of them have stressed that the workshop provides a refreshing change from the educational environment. In particular, they have highlighted the positive relationship with the students, as they assume the role of "coach" in the workshop, which is closer to the cooperative work environment that is usually found in a company or in an architecture studio. All participating lecturers agreed that the value of ToSCA lies in the roadmap, rather than the results. ToSCA is a challenge that must reach a new port each in order to give new knowledge to the sponsor company. However, the workshop's main value is the way that students and teachers work together throughout the week. This path has changed the position of future professionals in addressing technical problems. 


\section{DISSEMINATION}

The proposals produced by students during the last editions of ToSCA are available in the digital repository UPCopencourseware (http://ocw.upc.edu/curs/47052-2012/4).

The results are presented as a set of plates that represent the final contribution of each student group. Unfortunately, the materials are currently only available in Catalan and Spanish, but the challenge for the next workshops is to express the results in English, to allow students and teachers of other languages to consult and benefit from the experience.

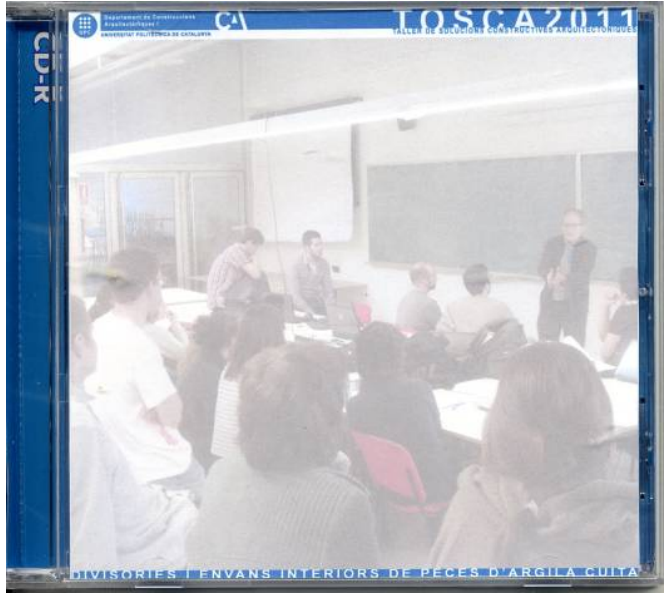

Front cover CD edition 2011

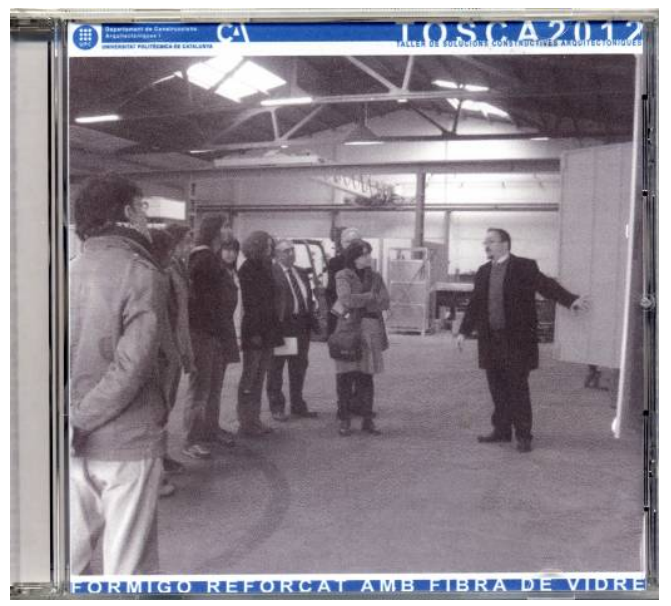

Front cover CD edition 2012

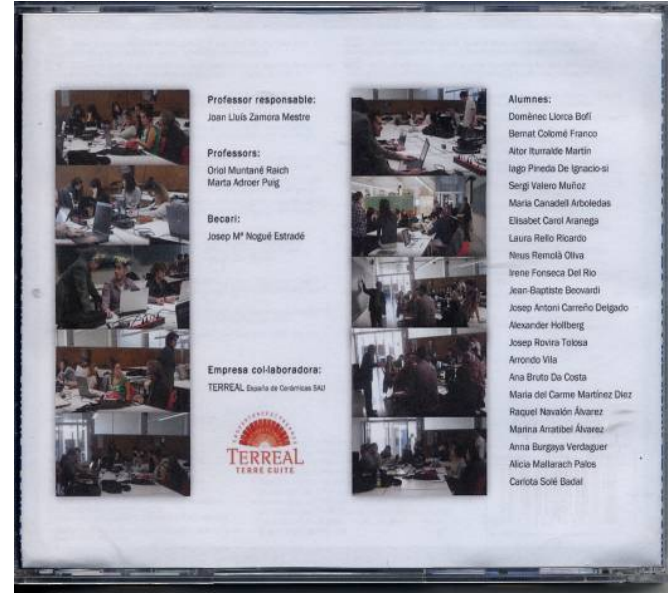

Back cover CD edition 2011

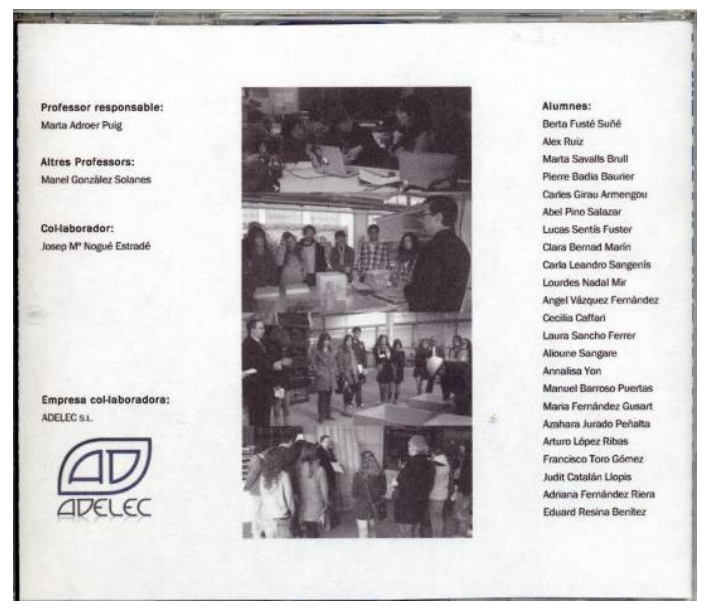

Back cover CD edition 2012 


\section{CONCLUSIONS}

- Education on architecture technologies through intensive workshops on technical innovation can be an exciting training process as valid as traditional project-based architectural design workshops. Students can play an active role in innovation under the supervision of a team of lecturers, generating innovative technical proposals that aim to meet future corporate and social needs.

- The experience of ToSCA suggests that greater continuity of training periods throughout the school calendar is also beneficial if new formats of educational activities are proposed for the transition between active and holiday periods.

- After the successive editions of the ToSCA workshop, the goals are still valid and the results published after each edition justifies the effort of the University in promoting technical innovation vocations. The work on groups by roles and with the active presence of the construction product companies is welcome.

ToSCA are grateful to the following professors for their participation: Marta Adroer, Manel Gonzalez, Roger Tudó and Oriol Muntané; the workshop are grateful too to the following junior lectures for their participation: Lara Sierra, Josep Ma Nogué and Paula Martín.

\section{REFERENCES}

[1] Addis, W., Building: 3000 years of design engineering and construction, London (2007) Ed. Phaidon

[2] Benavent de Barberà, P., Així es construeix: manual de l'obrer de la construcció, Barcelona (1964) Ed. Bosch

[3] Max-Neef, M.A., Desarrollo a escala humana, Montevideo (1993), Ed. Norman Comunidad

[4] Wagensberg, J., Si la naturaleza es la respuesta, ¿cuál era la pregunta? : y otros quinientos pensamientos sobre la incertidumbre, Barcelona (2003) Ed. Tusquets

[5] Kelley, T. \& Littman, J., Ten faces of innovation, www.tenfacesofinnovation.com

[6] Cornella, A. \& Flores, A., l'Alquímia de la Innovació, Bilbao (2007) Ed. Deusto

[7] Kieran, S. \& Timerlake, J, Refabricating Architecture: How Manufacturing Methodologies are Poised to Transform Building Construction (2003)

[8] Cain, T. Building Down Barriers: A Guide to Construction Best Practice (2003)

[9] The Four Steps to the Epiphany: Successful Strategies for Products that Win, Steven Gary Publication: Cafepress, 2005, Reference number: 9780976470700 